\title{
Peningkatan Creative Thinking Skill Peserta Didik melalui Model Cooperative Learning Berbantu Peta Konsep pada Tema Pencemaran Lingkungan
}

\author{
Lailil Mukarrom, Bayu Widiyanto, Yuni Arfiani
}

(C) 2019 JEMS (Jurnal Edukasi Matematika dan Sains)

This is an open access article under the CC-BY-SA license (https://creativecommons.org/licenses/bysa/4.0/) ISSN 2337-9049 (print), ISSN 2502-4671 (online)

\begin{abstract}
Abstrak:
Penelitian ini bertujuan mengetahui peningkatan creative thinking skill peserta didik antara penerapan model cooperative learning berbantu peta konsep dengan penerapan model cooperative learning tanpa peta konsep pada tema pencemaran lingkungan. Penelitian ini dilakukan pada peserta didik kelas VII di SMP Negeri 8 Pemalang. Desain penelitian ini adalah pretest-postest control group design. Teknik pengambilan sampel yang digunakan adalah purposive sampling. Pengujian penelitian ini menggunakan uji paired sample t-test. Instrumen yang digunakan yaitu soal pretest dan postest berbentuk uraian dengan 7 soal, lembar observasi dan lembar penilaian hasil tugas mandiri peserta didik. Hasil penelitian menunjukkan ada peningkatan yang signifikan dengan nilai signifikansi pada kelas eksperimen sebesar $0,016<0,05$ dan pada kelas kontrol sebesar $0,013<0,05$ antara penerapan model cooperative learning berbantu peta konsep dan model cooperative learning tanpa peta konsep untuk meningkatkan creative thinking skill peserta didik pada tema pencemaran lingkungan.
\end{abstract}

Kata Kunci : Cooperative Learning; Peta Konsep; Creative Thinking Skill; Pencemaran Lingkungan.

\begin{abstract}
:
This study aims to determine the improvement of students' creative thinking skills between the application of cooperative learning models assisted with concept maps and the implementation of cooperative learning models without concept maps on the theme of environmental pollution. This research was conducted on grade VII students at SMP Negeri 8 Pemalang. The design of this study was the pretest-posttest control group design. The sampling technique used was purposive sampling. The testing of this study used a paired sample t-test. The instrument used was a matter of pretest and posttest in the form of a description with seven questions, an observation sheet, and an assessment sheet of students' independent assignment results. The results showed a significant increase with a significance value in the experimental class of $0.016<0.05$ and in the control class of $0.013<0.05$ between the application of cooperative learning models assisted with concept maps and cooperative learning models without concept maps to improve participants' creative thinking skills students on the theme of environmental pollution.
\end{abstract}

Keywords : Cooperative Learning; Mapping Concept; Creative Thinking Skill; Environmental Pollution.

\section{Pendahuluan}

Manusia dan lingkungannya merupakan satu kesatuan yang tidak dapat dipisahkan, manusia memerlukan lingkungan sebagai tempat untuk hidup dan berkehidupan begitu pula lingkungan yang memerlukan manusia agar kelestarian ling-

Lailil Mukarrom, Universitas Pancasakti Tegal

mukarromlailil@gmail.com

Bayu Widiyanto, Universitas Pancasakti Tegal

bayuwidiyanto@upstegal.ac.id

Yuni Arfiani, Universitas Pancasakti Tegal

yuniarfiani@upstegal.ac.id 
kungan dapat terjaga (Thariq, 2014). Lingkungan merupakan kumpulan dari komponen lingkungan yang mempengaruhi secara langsung maupun tidak langsung dalam kehidupan. Komponen lingkungan terdiri dari 2 komponen yaitu komponen biotik (hidup) seperti manusia, hewan, tumbuhan dan komponen abiotik (tak hidup) seperti tanah, air, udara, dll.

Manusia sebagai salah satu komponen biotik (hidup) lingkungan selalu berusaha untuk berinovasi dan melakukan pengembangan di bidang ilmu pengetahuan dan teknologi. Kemajuan ilmu pengetahuan dan teknologi berdampak pada perubahan lingkungan. Munculnya masalah lingkungan diantaranya disebabkan karena ketidakmampuan masyarakat dalam mengembangkan sistem nilai sosial dan gaya hidup yang seimbang dengan lingkungan (Khanafiyah \& Yulianti, 2013). Berdasarkan pendapat tersebut, manusia cenderung memiliki sikap tidak peduli terhadap lingkungan dan menyebabkan lingkungan yang tidak seimbang.

Pencemaran lingkungan merupakan salah satu bentuk lingkungan yang tidak seimbang. Pencemaran lingkungan merupakan salah satu konsep biologi yang menunjang terlaksananya kegiatan praktik dan mendorong munculnya keterampilan proses, psikomotor dan afektif peserta didik (Fatmawati, 2016b). Pencemaran lingkungan merupakan masalah yang sering dijumpai di lingkungan sekitar kita dan perlu mendapat penanganan secara serius oleh semua pihak untuk dapat menanggulangi akibat buruk yang akan terjadi. Pencemaran lingkungan merupakan masalah kita bersama karena menyangkut kesehatan, keselamatan dan kehidupan kita. Permasalahan pencemaran lingkungan yang sedang terjadi diantaranya pencemaran air, tanah dan sungai, pencemaran udara, hujan asam, perubahan iklim global, penipisan lapisan ozon dan lain sebagainya.

Pencemaran lingkungan timbul akibat perilaku manusia yang konsumtif dan rendahnya pengetahuan tentang menjaga lingkungan. Contoh yang sederhana seperti manusia lebih sering membuang sampah di sungai dan di tempat sembarang tanpa berpikir akibat yang akan terjadi. Semakin banyaknya perusahaan juga salah satu akibat terjadinya pencemaran lingkungan. Limbah-limbah dari pabrik industri dibuang langsung ke sungai dan mengakibatkan air sungai menjadi tercemar.

Dalam kurikulum 2013 tingkat SMP/MTs pencemaran lingkungan menjadi salah satu materi yang berkaitan dengan lingkungan dan diajarkan di kelas VII semester 2. Materi pencemaran lingkungan di sekolah masih berpusat pada guru (Purnomo, Indrowati, \& Karyanto, 2013). Materi ini juga diberikan agar peserta didik lebih memahami berbagai masalah yang berkaitan dengan kondisi lingkungan saat ini. Oleh sebab itu, diperlukan model pembelajaran yang dapat menjadikan peserta didik lebih semangat dalam belajar khususnya pada materi pencemaran lingkungan, sehingga tujuan pembelajaran dapat tercapai.

Penggunaan model pembelajaran yang tepat sangat menentukan keberhasilan belajar peserta didik. Guru juga kurang mendukung aktivitas belajar karena metode pembelajaran yang sering digunakan sebatas ceramah dan penugasan (Rudyanto, 2014). Keberhasilan belajar peserta didik diantaranya seperti dapat mencakup aspek kognitif, afektif dan psikomotor serta peserta didik mencapai prestasi belajar yang tinggi dan dapat mengembangkan potensi yang dimiliki masing-masing peserta didik sehingga mereka akan lebih termotivasi untuk belajar IPA. 
Salah satu model pembelajaran yang digunakan untuk menarik perhatian peserta didik dengan menerapkan model cooperative learning berbantu peta konsep. Pada proses pembelajarannya peserta didik dituntut untuk bekerja sama dengan teman sekelompoknya untuk memahami suatu permasalahan. Oleh karena itu, model cooperative learning dapat menggunakan peta konsep untuk mempermudah peserta didik dalam memahami materi yang diajarkan dan melatih peserta didik untuk dapat bekerjasama dan creative thinking dalam membuat peta konsep suatu materi pembelajaran.

Peta konsep merupakan suatu diagram atau tabel yang menunjukkan hubungan antar konsep (Negoro, 2018). Berdasarkan pengertian tersebut peta konsep dapat diartikan sebagai gambar/diagram yang menunjukan antara konsep yang satu dengan konsep yang lain. Pembelajaran menjadi aktif jika menerapkan peta konsep karena peserta didik berperan aktif dalam pembelajaran yang dilaksanakan.

Manfaat penerapan model cooperative learning berbantu peta konsep salah satunya dapat menjadikan peserta didik creative thinking. Keterampilan berpikir kreatif (creative thinking skill) merupakan salah satu keterampilan abad 21. Creative thinking skill merupakan aktivitas mental yang terkait dengan kepekaan terhadap suatu masalah, mempertimbangkan informasi baru dan ide-ide yang tidak biasanya dengan suatu pikiran terbuka, serta dapat membuat hubungan-hubungan dalam menyelesaikan suatu masalah (Moma, 2015). Creative thinking skill merupakan salah satu keterampilan yang harus dimiliki oleh peserta didik. Penggunaan peta konsep dapat mengembangkan kreativitas masing-masing peserta didik dalam membuat sebuah peta konsep suatu materi pembelajaran. Selain itu, peta konsep juga dapat melatih peserta didik creative thinking kemudian memudahkan peserta didik dalam belajar untuk menguasai materi karena dalam menyusun peta konsep hanya menggunakan konsepkonsep atau poin-poin yang penting saja. Pembelajaran yang menggunakan peta konsep secara tidak langsung menerapkan pembelajaran student centered. Pembelajaran student centered merupakan pembelajaran menerapkan strategi pedagogi yang mengorietasikan peserta didik kepada situasi yang bermakna, kontekstual dan menyediakan sumber belajar saat mengembangkan pengetahuan tentang materi yang akan dipelajari (Ulya, Masrukan, \& Kartono, 2012). Berdasarkan uraian masalah yang dijelaskan diatas, maka dilakukan penelitian tentang implementasi model cooperative learning berbantu peta konsep terhadap creative thinking skill peserta didik pada tema pencemaran lingkungan.

\section{Metode}

Dalam penelitian ini, pendekatan yang digunakan yaitu pendekatan kuantitatif. Hal ini dikarenakan dalam memperoleh pengumpulan data, penelitian ini menggunakan penelitian yang turun langsung ke lapangan dengan menggunakan metode observasi atau pengamatan langsung dan metode tes. Jenis penelitian yang digunakan dalam penelitian adalah penelitian eksperimen. Penelitian ini terdapat kelas eksperimen dan kelas kontrol. Desain penelitian yang digunakan adalah pretest-posttest control group design.

Penelitian ini dilakukan di SMP Negeri 8 Pemalang dengan populasi semua peserta didik kelas VII. Teknik pengambilan sampel yang digunakan yaitu teknik purposuve sampling. Instrumen yang digunakan dalam penelitian ini yaitu soal pretest-postest, lembar observasi dan 
lembar penilaian hasil tugas mandiri. Untuk menyusun instrumen penelitian mengacu pada indikator creative thinking skill yaitu : berpikir lancar, berpikir luwes, elaborasi dan orisinal. Teknik analisis yang digunakan yaitu uji coba instrumen meliputi uji validitas, reliabilitas, tingkat kesukaran soal dan daya pembeda. Selanjutnya uji prasyarat analisis meliputi uji normalitas dan homogenitas. Kemudian uji hipotesis yang digunakan yaitu uji paired sample $t$ test untuk mengehtaui apakah ada pengaruh penerapan model pembelajaran copperative learning terhadap creative thinking skill peserta didik.

Langkah-langkah penelitian ini yaitu ada pertemuan pertama masing-masing kelas diberi perlakuan pretest yang bertujuan untuk mengetahui kemampuan awal peserta didik. Proses pembelajaran pada kelas kontrol yang menerapkan model pembelajaran cooperative learning tanpa peta konsep, peserta didik dibagi kelompok menjadi 6 kelompok dan berdiskusi dan merangkum membahas sub bab materi pencemaran lingkungan lalu mempresentasikan di depan kelas dan menjawab pertanyaan dari anggota kelompok lain. Kemudian pada pertemuan kedua, peserta didik melanjutkan presentasi hasil diskusi kelompok lalu setelah itu peserta didik diberi tugas mandiri berupa meresume sub bab materi pencemaran lingkungan. Setelah mengerjakan tugas mandiri, peserta didik mengerjakan postest yang bertujuan untuk mengetahui kemampuan peserta didik setelah proses pembelajaran.

Setelah diberi perlakuan pretest, pada kelas eksperimen yang menerapkan model pembelajaran cooperative learning berbantu peta konsep, peserta didik dibagi kelompok menjadi 6 kelompok dan berdiskusi untuk membuat peta konsep. Setiap kelompok berusaha untuk membuat peta konsep yang unik dan menarik karena dalam hal ini untuk mengukur creative thinking skill peserta didik (Annisah, 2014). Selanjutnya peserta didik mempresentasikan hasil peta konsep kelompok di depan kelas. Pada pertemuan kedua, melanjutkan presentasi hasil peta konsep kelompok. Setelah presentasi selesai, peserta didik diberi tugas membuat peta konsep secara individu untuk mengetahui creative thinking skill peserta didik. Setelah itu, peserta didik mengerjakan postest yang bertujuan untuk mengetahui kemampuan peserta didik setelah proses pembelajaran.

\section{Hasil dan Pembahasan}

Penelitian ini dilakukan pada kelas VII semester 2 di SMP Negeri 8 Pemalang. Sekolah ini sudah memberlakukan kurikulum 2013 untuk seluruh kelas dan untuk mata pelajaran IPA untuk KKM kelas VII sebesar 65. Populasi pada penelitian ini adalah seluruh peserta didik kelas VII dan pengambilan sampel menggunakan purposive sampling Penelitian ini dilaksanakan pada tanggal 30 Maret sampai dengan 4 April 2019. Kelas eksperimen dalam penelitian ini adalah kelas VII E. Kelas kontrol penelitian ini adalah kelas VII E. Jumlah peserta didik pada kelas kontrol dan kelas eksperimen yaitu masing-masing 28 peserta didik.

Tabel 1 Data Hasil Pretest dan Postest Kelas Eksperimen

\begin{tabular}{cccccc}
\hline & N & Mean & Std. Deviation & Minimum & Maximum \\
\hline Pretest & 28 & 58,43 & 8,796 & 46 & 74 \\
Postest & 28 & 63,50 & 8,930 & 49 & 80 \\
\hline
\end{tabular}


Tabel 2 Data Hasil Pretest dan Postest Kelas Kontrol

\begin{tabular}{lccccc}
\hline & N & Mean & $\begin{array}{c}\text { Std. } \\
\text { Deviation }\end{array}$ & Minimum & Maximum \\
\hline Pretest & 28 & 51,00 & 8,032 & 40 & 71 \\
Postest & 28 & 55,50 & 8,302 & 43 & 74
\end{tabular}

Tabel 1 dan Tabel 2 menunjukkan bahwa nilai rata-rata pretest pada kelas kontrol maupun eksperimen, diperoleh hasil yang rendah. Hasil nilai rata-rata pretest yang rendah tersebut juga sejalan dengan penelitian (Isthofiyani, Prasetyo, \& Iswari, 2016) yang mengungkapkan bahwa persepsi masyarakat cenderung rendah akibatnya banyak orang sering membuang sampah di sungai, pencemaran limbah pabrik yang dibuang sembarangan, serta tidak memperdulikan lingkungan sekitar. Peserta didik yang merupakan bagian dari masyarakat juga harus memahami dan menguasai pengetahuan tentang pencemaran lingkungan agar dapat menanggulangi pencemaran lingkungan.

Tabel 1 dan Tabel 2 menunjukkan ada peningkatan setelah proses pembelajaran dilakukan. Hal ini dibuktikan dengan nilai rata-rata pada soal pretest sebesar 58,43 sedangkan pada nilai rata-rata soal postest sebesar 63,50. Seperti halnya Tabel 1, Tabel 2 juga menunjukkan ada peningkatan setelah proses pembelajaran dilakukan .Tetapi nilai rata-rata peningkatan hanya sedikit selisiihnya yaitu nilai rata-rata soal pretest sebesar 51 dan nilai rata-rata postest 55,50.

Tabel 3 Data Hasil Observasi Creative Thinking Skill Kelas Eksperimen dan Kelas Kontrol

\begin{tabular}{lcc}
\hline \multirow{2}{*}{ Ukuran } & \multicolumn{2}{c}{ Nilai } \\
\cline { 2 - 3 } & Kelas Eksperimen & Kelas Kontrol \\
\hline Mean & 76 & 73 \\
Median & 75 & 75 \\
Modus & 83,3 & 66,67 \\
Tertinggi & 92 & 92 \\
Terendah & 75 & 67 \\
Standar Deviasi & 7,54 & 7,64 \\
\hline
\end{tabular}

Berdasarkan hasil observasi yang dilakukan pada saat proses pembelajaran berlangsung, diperoleh nilai rata-rata pada kelas eksperimen sebesar 76 dan pada kelas kontrol 73. Selisih nilai rata-rata tersebut dikarenakan dalam proses pembelajaran peserta didik pada kelas eksperimen belum terbiasa belajar dengan membuat peta konsep karena pembuatan peta konsep menyita waktu yang cukup banyak. Akan tetapi, pada kelas eksperimen dalam diskusi presentasi dan tanya jawab, peserta didik lebih aktif dan lebih termotivasi dalam proses pembelajaran dibanding kelas kontrol. Hasil peningkatan menggunakan metode peta konsep juga sejalan dengan penelitian (Hartantio \& Buditjahjanto, 2014) yang mengungkapkan bahwa ada peningkatan yang signifikan setelah diterapkan metode peta konsep dalam proses pembelajaran. 
Tabel 4 Hasil Uji t Pengaruh Penggunaan Peta Konsep

\begin{tabular}{llll}
\hline & & & \\
& & thitung & Sig. (2-tailed) \\
& & \\
\hline Creative Thinking Kelas Eksperimen & -2.581 & 0.016 \\
Skill & Kelas Kontrol & -2.672 & 0.013 \\
\hline
\end{tabular}

Metode yang menggunakan peta konsep juga dapat membuat menarik suasana pembelajaran, memotivasi peserta didik dan menyenangkan proses pembelajaran. Peta konsep juga baik digunakan untuk meningkatkan daya hafal dan daya kreativitas peserta didik. Hal ini didukung penelitian (Fauziah, Masykuri, \& Nugroho, 2013) yang mengungkapkan bahwa peta konsep merupakan salah satu metode pembelajaran yang sangat baik digunakan oleh guru untuk meningkatkan daya hafal dan pemahaman konsep peserta didik, serta peserta didik juga dapat meningkatkan daya kreativitasnya.

Peta konsep merupakan teknik ringkas konsep pokok yang ditulis sedangkan untuk menjabarkannya peserta didik dapat menggunakan kalimatnya sendiri. Pada kelas eksperimen, peserta didik lebih dapat memahami materi yang disampaikan jika pembelajaran berbantuan peta konsep karena peserta didik lebih bersemangat dalam belajar.

Tabel 4 menunjukkan hasil analisis uji t dengan persamaan taraf $5 \%(0,05)$ diperoleh nilai signifikansi pada kelas eksperimen sebesar 0,016<0,05 dan pada kelas kontrol sebesar 0,013<0,05. Hasil ini menunjukkan bahwa terdapat peningkatan creative thinking skill peserta didik pada kelas eksperimen dan kelas kontrol setelah proses pembelajaran dilakukan. Peserta didik juga lebih dapat berkreasi dalam memahami materi yang disampaikan.

Tabel 5 Data Penilaian Hasil Tugas Mandiri

Kelas Eksperimen dan Kelas Kontrol

\begin{tabular}{lcc}
\hline \multirow{2}{*}{ Distribusi data } & \multicolumn{2}{c}{ Nilai } \\
\cline { 2 - 3 } & Kelas Eksperimen & Kelas Kontrol \\
\hline Mean & 81 & 68,75 \\
Median & 84 & 75 \\
Modus & 88 & 75 \\
Tertinggi & 94 & 88 \\
Terendah & 75 & 69 \\
Standar Deviasi & 6,38 & 5,76 \\
\hline
\end{tabular}

Tabel 5 memperlihatkan hasil penilaian tugas mandiri, diperoleh nilai rata-rata 81 di kelas eksperimen dan nilai rata-rata sebesar 68,75 di kelas kontrol. Selisih nilai rata-rata tersebut cukup signifikan karena pada kelas eksperimen, peserta didik lebih kreatif dalam mengerjakan tugas mandiri berdasarkan indikator creative thinking skill. Hal ini menunjukkan bahwa ada perbedaan creative thinking skill peserta didik antara kelas eksperimen dan kelas kontrol yang cukup siginifikan. 
Tabel 6 Persentase Indikator Creative Thinking Skill

Peserta Didik

\begin{tabular}{lcc}
\hline Indikator Creative Thinking & \multicolumn{2}{c}{ Rata-rata (\%) } \\
\cline { 2 - 3 } Skill & Kelas Eksperimen & Kelas Kontrol \\
\hline Keaslian (originality) & 70 & 69 \\
Keluwesan (flexibility) & 85 & 68 \\
Penguraian (elaboration) & 84 & 78 \\
Kelancaran (fluency) & 87 & 66 \\
\hline
\end{tabular}

Tabel 6 memperlihatkan hasil penilaian tugas mandiri, diperoleh presentase indikator creative thinking skill. Pada indikator keaslian persentase yang di dapat sebesar $61 \%$. Hal ini dikarenakan pada hasil pembuatan peta konsep peserta didik hanya menggunakan bentuk (shape) dan kata kunci yang sedikit berbeda dari kebanyakan orang. Peserta didik juga merasa kesulitan saat diberi tugas untuk membuat peta konsep terbaru dan jarang dibaut orang kebanyakan orang.

Pada indikator keluwesan persentase yang didapat sebesar $81 \%$. Hal ini dikarenakan pada pembuatan peta konsep peserta didik dapat membuat peta konsep dengan konsep yang sudah dipelajari sebelumnya minimal 15 konsep dengan waktu yang cepat. Peserta didik merasa mudah karena konsep-konsep yang dibuat sudah ada dan hanya mengembangkannya menjadi lebih baik.

Pada indikator penguraian persentase yang didapat sebesar $84 \%$. Peserta didik dapat menguraikan secara rinci dan mendalam dengan banyak cabang konsep yang telah dibuat peerta didik merasa senang dalam pembuatan peta konsep karena disamping membuat, peserta didik juga dapat memahami dan dapat menguraikan dengan baik.

Indikator kelancaran (fluency)

Pada indikator kelancaran, persentase yang didapat paling tinggi dibanding indikator lain yaitu sebesar $87 \%$. Hal ini dikarenakan peserta didik dapat membuat tampilan gambar yang menarik dan mudah dipahami pada hasil pembuatan peta konsep.

Keunikan penelitian ini adalah peserta didik dapat belajar membuat peta konsep sendiri dan dengan kreativitasnya masing-masing. Peta konsep juga dapat membuat peserta didik lebih memahami materi yang disampaikan yang didukung oleh hasil presentase indikator creative thinking skill yang cukup tinggi. Hal ini juga sejalan dengan penelitian (Yunita, 2014) menyatakan bahwa penggunaan metode peta konsep dalam proses pembelajaran lebih mudah dipahami, serta mempermudah proses penyerapan materi pelajaran di kelas. Peta konsep juga sangat efektif digunakan dalam proses pembelajaran untuk memberikan hasil yang signifikan.

Model cooperative learning berbantu peta konsep ini memiliki beberapa kendala diantaranya berkaitan dengan waktu yang diperlukan cukup banyak. Selain itu, guru yang akan menerapkan pembelajaran berbantu peta konsep harus benar-benar menguasai dan memahami peta konsep sehingga pembelajaran dapat dilakukan secara maksimal. Pada saat saling mengungkapkan ide masing-masing membuat suasana kelas tidak kondusif.

Hasil dari penelitian yang dilakukan dapat dikatakan bahwa penerapan model cooperative learning berbantu peta konsep dapat diterapkan dalam pembelajaran IPA khususnya pencemaran lingkungan karena peserta didik dapat mengungkapkan ide-idenya melalui peta 
konsep secara creative thinking skill yang merupakan keterampilan abad ke-21 yang harus dimilki oleh peserta didik.

Berdasarkan kendala yang dialami pada penelitian ini, diperlukan untuk penelitian selanjutnya yaitu sering diterapkan metode peta konsep pada proses pembelajaran. Guru juga harus dapat menguasai dan memahami pembelajaran berbantu peta konsep serta pengelolaan waktu juga diperhatikan agar efektif dan efisien serta suasana kelas dapat kondusif.

\section{Simpulan}

Simpulan penelitian ini yaitu peningkatan creative thinking skill peserta didik pada kelas eksperimen dan kelas kontrol dengan nilai signifikansi nilai signifikansi pada kelas eksperimen sebesar 0,016<0,05 dan pada kelas kontrol sebesar 0,013<0,05.

\section{Daftar Rujukan}

Annisah, S. (2014). Penerapan Metode Mind Map Dalam Meningkatkan Kemampuan Berfikir Kreatif Mahasiswa. Jurnal Tarbiyah, 21(1), 223-242.

Fauziah, N., Masykuri, M., \& Nugroho, A. (2013). Studi Komparasi Metode Pembelajaran Student Teams Achievement Division (Stad) Menggunakan Peta Pikiran Dan Peta Konsep Terhadap Prestasi Belajar Siswa Pada Materi Pokok Sistem Periodik Unsur Siswa Kelas X Semester Ganjil Sma Negeri Kebakkramat Tahun Pelaj. Jurnal Pendidikan Kimia, 2(2), 132-139.

Hartantio, Y., \& Buditjahjanto, I. A. (2014). Penerapan Strategi Belajar Peta Konsep (Mind Mapping) Untuk Meningkatkan Hasil Belajar Siswa Pada Standar Kompetensi Menerapkan Dasar-Dasar Elektronika Digital Di Smkn 1 Driyorejo. Jurnal Pendidikan Teknik Elektro, 3(1), 133-140.

Isthofiyani, S. E., Prasetyo, A. P. B., \& Iswari, R. S. (2016). Persepsi Dan Pola Perilaku Masyarakat Bantaran Sungai Damar Dalam Membuang Sampah Di Sungai. Journal Of Innovative Science Educations, 5(2).

Khanafiyah, S., \& Yulianti, D. (2013). Model Problem Based Instruction Pada Mengembangkan Sikap Kepedulian Lingkungan. Jurnal Pendidikan Fisika Indonesia, 9, 35-42.

Moma, L. (2015). Pengembangan Instrumen Kemampuan Berpikir Kreatif Matematis Untuk Siswa Smp. Jurnal Matematika Dan Pendidikan Matematika, 4(1), 27-41.

Negoro, R. A. (2018). Upaya Membangun Keterampilan Berpikir Kritis Melalui Peta Konsep. Jurnal Pendidikan (Teori Dan Praktik), 3, 45-51.

Purnomo, D., Indrowati, M., \& Karyanto, P. (2013). Pengaruh Penggunaan Modul Hasil Penelitian Pencemaran Di Sungai Pepe Surakarta Sebagai Sumber Belajar Biologi Pokok Bahasan Pencemaran Lingkungan Terhadap Hasil Belajar Siswa. Jurnal Pendidikan Biologi, 5(1), 59-69. 
Rudyanto, H. E. (2014). Model Discovery Learning Dengan Pendekatan Saintifik Bermuatan Karakter Untuk Meningkatkan Kemampuan Berpikir Kreatif. Premiere Educandum, 4(1), 41-48.

Thariq, A. (2014). Upaya Pemeliharaan Lingkungan Oleh Masyarakat Di Kampung Sukadaya Kabupaten Subang. Jurnal Geo, 14(2), 124-134 